\title{
The Partnership Conception of Democracy
}

\author{
Ronald Dworkin $\dagger$
}

Professor Michelman takes up a central issue of political and constitutional theory in his intriguing Brennan Lecture-the bewitching idea that democracy means self-government. We say that democracy is valuable because in a democracy the people govern themselves, and it is this sense, rather than any supposed instrumental advantages democracy enjoys over other forms of government, that explains its great contemporary popularity. But we have great difficulty in stating what the claim of self-government ineans. Democracy cannot provide self-government in the inost literal sense: individual citizens cannot have a veto on law or policy. If the claim means only that a majority of the people governs, it is hard to see how that provides anything of value for individual citizens. Why is my vote important or valuable to me if it is only one among millions?

So the problem of self-government is an interpretive challenge. We must either develop an account or conception of democracy that redeems the rhetoric of self-government, or concede that the rhetoric is empty, only a sugar coating around the bitter pill of majoritarianism. I tried to construct a redeeming conception of democracy in my recent book, Freedom's Law.' Its central hypothesis is that the citizens of a political community govern themselves, in a special but valuable sense of self-government, when political action is appropriately seen as collective action by a partnership in which all citizens participate as free and equal partners, rather than as a contest for political power between groups of citizens. I used that hypothesis to construct what I called a constitutional or partnership conception of democracy. Michelman devotes part of his lecture to this hypothesis, and reports that he is not persuaded by it. He thinks I have committed the serious fallacy of "mistak[ing] a case of affect or attitude for a case of agency."

\footnotetext{
Copyright @ 1998 Ronald Dworkin and California Law Review, Inc.

$\dagger$ Professor of Jurisprudence, Oxford University, and Professor of Law, New York University.

1. Ronald Dworkin, Freedom's Law (1996).

2. Frank I. MicheIman, Brennan and Democracy, 86 CaLIF. L. Rev. 399, 418 (1998).
} 
I shall return to his extended critique of my proposal, but only after first considering his own alternative suggestion. Michelman, like myself, is anxious to salvage democracy's claim of self-government: he wants to display democracy as a "state of self-government, in as full a sense as we can reasonably hope to find in politics." The question is: How full a sense is that? Michelman's answer is a Kantian one: he says that people govern themselves when they obey the laws of their community out of a respect for those laws that is generated by confidence in the fundamental constitutional structure, and he explains the role of justices like Brennan as contributing to that confidence. But that supposed form of "self-government" does not require democracy: the subjects of a dictatorship would govern themselves, in Michelman's version of the Kantian sense, as long as they thought that the dictator's methods of decision were fair and wise. Michelman may assume that no one would now think any but a democratic constitutional structure a fair one. But that assumption does not show any sense in which democracy in itself constitutes government of a people by themselves. Nor does it show why people who think that their nation's deinocratic constitution is imperfect-flawed in wisdom and fairness-are nevertheless governing themselves uuder it. Perhaps it is Michelman's final (and, in his word, "dark") judgment, that we cannot "reasonably hope to find" any more in the idea of self-government than his unpersuasive Kantian construction reveals, and that we should abandon the old rhetoric.

If you wish to avoid that depressing conclusion, turn back to the hypothesis Michelman criticizes-that democracy supplies an important kind or mode of self-government when it is a democracy of equal political partners. A series of questions arises. Under what circumstances is political action rightly regarded as the collective action of equal partners? In what sense is political action better when it can be so regarded-why is a political structure that offers partnership to all its citizens more desirable than one that does not? Is it an appropriate way to describe these benefits to say that such a structure provides its citizens with self-government?

I began my answers to these various questions with a suggestion whose intended force Michelman has misunderstood. Many of us already hold a belief we can exploit to defend the partnership conception of self-government. We believe that under some circumstances we are jointly responsible, as individuals, for the consequence of the collective action of groups to which we belong-that we share a responsibility for the collective achievements or failures that goes beyond our responsibility, as individuals, for our own contribution to that action. We say "we did it," and we take a vicarious pride or shame in the result that is

3. Id. at 424 . 
quite independent of any pride or shame we might take in what we each, as individuals, have done. We are ethically integrated with the community. We feel, in other words, that our own responsibility as individuals is at stake in what the community, as a distinct agent through which we act vicariously, has done. I believe that the collective guilt of some Americans about their country's war in Vietnam, which is shared by many who did their best to oppose that war, is an example of this phenomenon of ethical integration, and I have offered a variety of other examples. ${ }^{4}$

These examples, which call attention to what I believe is an important part of many people's ethical and moral experience, presumably prompted Michelman's objection that I have confused belief or feeling with agency. I meant to appeal, however, not to the psychological fact that many people do have the belief I described, but to the moral fact the belief expresses. I claim that in certain circumstances people do share responsibility for the collective acts of groups to which they belong, whether they recognize this or not. That is a moral or ethical not a psychological claim. I called attention to the familiarity of the belief in such collective responsibility, as I said, in hopes of leading my readers to realize that they already held that belief, but it is the truth of the belief, not its popularity, on which my argument depends.

Suppose it is true that under soine circumstances we do share a collective responsibility for the actions of groups to which we belong, and we share that responsibility even though we did not contribute toindeed, even if we dissented from-particular actions. One way to report that moral fact would be in the language of agency: we report it when we say that we are all responsible, for better or worse, for something that "we" have done. However, that language is appropriate, as a serious claim, only when the circumstances of shared responsibility, whatever these might be, in fact hold. A neinber of a baseball team that has won a pennant may say "we did it" with no sense of irony. But a coinmodity broker whose trades, along with those of thousands of other brokers, raised the price of orange juice futures to a record high cannot, because he acted, not as a partner in an enterprise, but only by and for himself. The broker's action is collective only in a statistical sense.

I do not mean (I must emphasize) that the language of agency is appropriate in virtue of the actual causal contribution of each participant: the baseball player who properly says "we did it" may have struck out four times. Nor do I mean that the language of agency is appropriate because the individual participants are only aspects or dimensions of a more fundamental causal agent which is the group itself. There is nothing of Hegel in the thought that leads most people to say, of soine collective action, that "we" did it. The language of agency is

4. See, e.g., DWoRkIN, supra note 1, at 20. 
appropriate for a reason that is independent of any causal claim: it is appropriate because responsibility is an independent part of the concept of agency. In most cases someone whose individual action causes a particular result is responsible for that result: the two ideas go together in our attribution of agency to him. In some cases, however, causal impact is separated from responsibility, as when someone's reflex action causes injury, and we then say that it was his act only in a special and more limited sense. Collective agency is an example of an opposite kind of separation, when we have responsibility without causal impact, and that explains, I think, our temptation to say that this, too, is a kind of agency, though again a special and limited one.

These last observations are directed only to the third of the three questions I distinguished-whether the moral phenomenon of shared responsibility for collective action is properly associated with agency and therefore, in the political case, with self-government. This linguistic question is not, however, as important as the other, more substantive, questions I listed. Under what circumstances, I asked, would it be appropriate to describe a political structure as one that creates a political partnership embracing all citizens? I can now begin an answer using, once again, the phenomenon of ethical integration that $I$ tried to isolate. It is a necessary condition of political partnership that the relations among the citizens, and between them and the government they create, are such as to give each citizen, whether he recognizes it or not, a share in collective responsibility for the community's political decisions. Of course, that answer merely restates the question, but it does so in a way that makes plain its status as a moral question, and points to a line of relevant inquiry.

Ethical integration in the collective action of a community to which one in some sense belongs is not always appropriate and is sometimes perverse. It would surely have been perverse for the German Jewish victims of the Holocaust to feel a shared shame for it. Nor is ethical integration appropriate in the more mundane cases of action that is collective only in what I called a statistical sense. None of the commodity brokers who collectively set a record price for orange juice futures would be justified in taking either pride in or blame for that record. Nor is it appropriate for those whom the community does not recognize as full members, even when they participate in its political life. It would be wrong for members of a racial minority to accept a shared responsibility for political decisions that systematically ignored their own needs and fate, even if they were each allowed an equal vote in the majoritarian processes that produced those decisions.

Ethical integration with the collective acts of a political society is only appropriate, that is, for citizens whom the society treats as full and 
equal members of it. I have tried to spell out, at great length, what I take the consequences of that claim to be, and I shall only summarize my conclusions here. ${ }^{5}$ Citizens have shared responsibility for political decisions in, but only in, a democracy that provides every citizen substantial equality of part and voice in its collective decisions, that recognizes the equal importance of every citizen's fate in deliberating and executing those collective decisions, and that guarantees each individual a sovereign immunity from such collective decisions over certain matters of conscience and faith that, as a matter of self-respect, people must decide for themselves.

These conclusions have an important consequence: they merge two ideas that have often been thought to be opposed-democracy and constitutional rights-into the distinct ideal of political partnership. It seems essential to the idea of democracy that democracy provides selfgovernment, but we can claim that essential connection only if we conceive democracy as something more than majority mle. We must understand it as a kind of partnership among citizens that presupposes individual rights as well as majoritarian procedures. But that brings us to the second question I distinguished. If that is what self-government means, why should we want it? Self-government in the individualistic sense-having a veto over political decisions-is evidently and straightforwardly valuable because it includes control. But self-government in the collective sense-government by a partnership in which one is a free and equal partner-does not give control. Why should we care whether we are self-governing in that sense? How can self-government be important apart from control?

Once again the idea of a shared responsibility for collective action seems to provide an answer, because it invites us to look at the idea of partnership as itself a source of value. It is valuable to work with others as partners toward something important, both because that kind of relationship with other people is ethically satisfying, at least to many people, and because, particularly in politics, the conditions of equality and respect that make it possible are independently good. So we do, after all, make a large and important claim when we say that democracy means self-government, and we must do our best, as lawyers and scholars and citizens, to realize what that claim really means.

I might close this brief defense of the partnership conception of democracy by taking up another of Michelman's themes: the contrast between what he calls procedural and substantive conceptions of democracy. The conditions of political partnership plainly require certain majoritarian political procedures, as my quick summary of those conditions made clear. Citizens are not offered an equal role in government

5. See Dworkin, supra note 1, at 1-38. 
unless their representatives are chosen in periodic elections in which no one has more votes than anyone else. But majoritarian procedures do not themselves necessarily provide or protect the conditions of partnership and shared responsibility. Individual rights of equality and freedom must be in place and protected from the majority as well. It is, I agree, a particularly healthy state of affairs when the conditions that make partnership possible are themselves endorsed by the vast bulk of the partners: when the partnership creates and recreates itself. But it would be a mistake to suppose that the only genuine democracy is one that has been created only in accordance with, or is sustained only by, the will and blessing of the people as a whole. We must take a more result-oriented approach: we must judge a political system by its capacity to improve the conditions of genuine political partnership, and not rule out as undemocratic any institution or device, including a constitutional court, that history has shown strengthens that capacity. It would be perverse to condemn, on democratic grounds, any part of what has made ours a better democracy. 